\title{
Pollen preference of the Chrysoperla species (Neuroptera: Chrysopidae) occurring in the crop environment in western France
}

\author{
JOHANNA VILLENAVE ${ }^{1}$, Bruno DEUTSCH${ }^{2}$, ThIERry LODÉ ${ }^{3}$ and ElIZABETh RAT-MORRIS ${ }^{1}$ \\ ${ }^{1}$ Institut National d'Horticulture, Unité de Protection des Plantes, 2 rue Le Nôtre, F-49045 Angers Cedex, France; \\ e-mail: johanna.villenave@inh.fr \\ ${ }^{2}$ Institut de Mathématiques Appliquées, Université Catholique de l'Ouest, F-49000 Angers, France \\ ${ }^{3}$ Laboratoire d'Ecologie Animale, U.F.R. Sciences, Université d'Angers, Campus de Belle-Beille, F-49045 Angers Cedex, France
}

Key words. Neuroptera, Chrysopidae, common green lacewing, conservation biological control, Chrysoperla, oesophageal diverticulum contents, pollen, preference, attractive plants, western France, crop environment

\begin{abstract}
Two species of the Chrysoperla carnea complex: Ch. carnea sensu Henry and Ch. lucasina, occur in the crop environment in western France. Within the framework of a conservation biological control program for protected seed crops, the pollen consumption of these common green lacewings was investigated. The diverticulum contents of collected specimens were analysed to determine their food preference. Ch. carnea sensu Henry and Ch. lucasina are opportunistic feeders, which are attracted to large patches of flowering plants. The establishment of monitoring an attractive environment for these predators is discussed.
\end{abstract}

\section{INTRODUCTION}

The demand for high quality food in West European markets has increased significantly making Integrated Pest Management and organic farming attractive options for both farmers and agronomists. Crops must be free of pesticides and so they need to be protected against phytophagous pests by other means. Barbosa (1998) emphasised the attraction of beneficial insects to crop environment, and their migration to the under-cover crops and the greenhouses (conservation biological control). The vegetation bordering or surrounding cultivated areas provide oviposition and overwintering sites, a wider choice of food and shelter for beneficial organisms (Thies \& Tscharntke, 1999; Nicholls \& Altieri, 2002), and contribute to the diversity of plant species (Theunissen \& Den Ouden, 1980; Baliddawa, 1985). Several methods of attracting pollinators (Yeboah Gyan \& Woodell, 1987), and entomophagous insects such as Syrphidae (Colley \& Luna, 2000), Coccinellidae (Hodek, 1973) and Neuroptera (Hagen et al., 1976) have been proposed. Among the latter, the larvae of green and brown lacewings have many favourable traits such as a great voracity and a wide range of prey (New, 1975). Chrysoperla spp. are the most frequent and abundant green lacewings in crops in temperate regions (Duelli, 2001). The life history of Chrysoperla is complex, its larvae are entomophagous, while the adults feed mainly on substances of vegetal origin (nectar and pollen) but also insect honeydew (Principi \& Canard, 1984; Stelzl, 1991; Bozsik, 1992). Their flight behaviour is of three types: (i) migration to overwintering sites after diapause induction in late summer (Thierry et al., 1994), (ii) migration to the field crops and the surrounding trees and bushes in spring (Duelli, 2001; Villenave et al., 2005), and (iii) preoviposition flights to new habitats with aphid colonies (Duelli, 2001). Chrysoperla carnea (Ste- phens) sensu Henry [= Chrysoperla affinis (Stephens) sensu Thierry], has a larger plant range than Ch. lucasina (Lacroix) (Villenave et al., 2005). Ecological requirements can account for the differences in feeding behaviour of these sibling species of the carnea complex (Thierry et al., 1992): Ch. lucasina frequently occurs in field crops and on herbaceous plants in summer (Henry et al., 1996; Paulian, 2001) while the other species lives on bushes and herbaceous plants (Thierry et al., 1996). Within their habitat, however, adults choose their food. Are they attracted by particular plants or do they move and feed at random? First, the consumption of pollen of particular plants by common green lacewings was compared to the availability of polliniferous plants. Then, plant attractiveness was analysed more accurately. This work aims to determine the food-choice of common green lacewings in a crop environment by comparing the availability of pollen with the diverticulum contents of the lacewings.

\section{MATERIAL AND METHODS}

This work was carried out in the Loire Valley in western France, near Angers in four agroecosystems devoted to seed protected production. At each site, the study was carried out in about 3 ha of various crops (cabbage, leek, carrot or alfalfa). The surrounding vegetation consisted of hedges with various trees and bushes, and scattered weeds (Table 1).

The floristic composition of the different sites was similar because of their geographical proximity. Three sites were on calcareous soil (Parisian Basin) and the fourth, on soil derived from schist and sandstone (Armorican Massif).

\section{Survey of Chrysopidae}

Green lacewing adults of Chrysoperla spp., were sampled every 2 weeks from March to October 2004, in herbaceous and crop vegetation, and the tree canopy. In the low growing vegetation, they were sampled for $10 \mathrm{~min}$ using a mobile vacuum 
TABLE 1. Characters of field crops and surrounding vegetation in the Loire Valley in western France where this study was carried out, during the period March to October 2004.

\begin{tabular}{|c|c|c|c|c|}
\hline Sites (km from Angers) & Main flowering field crops & Hedges & Surrounding vegetation & Geological origin of soil \\
\hline $\begin{array}{l}\text { Beaufort-en-Vallée } \\
\text { (32) }\end{array}$ & Alfalfa & Various species & Scattered weeds & $\begin{array}{l}\text { Parisian Basin } \\
\text { calcareous }\end{array}$ \\
\hline $\begin{array}{l}\text { Ambillou-Château } \\
\text { (33) }\end{array}$ & $\begin{array}{l}\text { Cabbage } \\
\text { Leek }\end{array}$ & $\begin{array}{c}\text { Rosaceae }(\text { Prunus...) } \\
\text { Betulaceae }\end{array}$ & Few flowering weeds & $\begin{array}{l}\text { Parisian Basin } \\
\text { calcareous }\end{array}$ \\
\hline $\begin{array}{l}\text { Noyant-la-Plaine } \\
\text { (31) }\end{array}$ & $\begin{array}{c}\text { Cabbage } \\
\text { Leek } \\
\text { Carrot }\end{array}$ & No hedges & $\begin{array}{c}\text { Very few } \\
\text { flowering weeds }\end{array}$ & $\begin{array}{l}\text { Parisian Basin } \\
\text { calcareous }\end{array}$ \\
\hline $\begin{array}{l}\text { Neuvy-en-Mauges } \\
\text { (39) }\end{array}$ & $\begin{array}{l}\text { Cabbage } \\
\text { Leek } \\
\text { Carrot }\end{array}$ & $\begin{array}{c}\text { Fagaceae } \\
\text { Rosaceae } \\
(\text { Prunus, Malus...) } \\
\text { Betulaceae }\end{array}$ & Scattered weeds & $\begin{array}{c}\text { Armorican Massif } \\
\text { schist and sand stone }\end{array}$ \\
\hline
\end{tabular}

device, and in the canopy by means of two hundred sweeps of a hand net (net $50 \mathrm{~cm}$ in diameter and $80 \mathrm{~cm}$ deep).

Seasons are as follows: spring week 14 to 22 , summer 24 to 36 and autumn 38 to 44 . The species of Chrysoperla were identified using the morphological characteristics recommended by Thierry et al. (1998) with the identity of some living specimens confirmed by reference to the vibrational song recorded by Henry et al. (1996, 2002).

\section{Survey of flora}

All plants were listed to evaluate the abundance of each taxa at each site. Plant occurrence is expressed as percentage of surface occupied by each family at each sample site. The flowering period of each plant species was noted (Table 4, Fig. 1).

\section{Analysis of gut contents}

The adult chrysopids were killed at $-80^{\circ} \mathrm{C}$ and preserved until required in a freezer. The oesophageal diverticula were removed from these specimens. This part of the gut serves as a reservoir where pollen and other materials are stored but not digested. The diverticulum was cut open on a slide and the pollen exposed. After the lipid was extracted using diethyl ether, the diverticulum was placed on a slide with glycerin jelly containing basic fuchsin, which stained the pollen (Hyde \& Adams, 1958). Pollen was examined under an optic microscope at a magnification of 400 times and determined to family or species level using as a reference the INRA - Le Magneraud's pollen collection (Aupinel et al., 2001). The quantity of pollen was estimated by recording the total number of pollen grains visible at magnification of 20 times in each diverticulum. The size of the diverticulum is ranged from $2 \mathrm{~mm}$ (empty) to $3 \mathrm{~mm}$ (full). Honeydew is identified by the presence of arthropod exuviae, a few exotic pollen and spores of fungi such as Cladosporium and Alternaria sp. (Hagen \& Tassan, 1972).

\section{Statistical analyses}

Statistical analyses were carried out to test if the common green lacewing consumed pollen at random or was attracted to certain plants. As not all pollen can be identified to species, the statistical analysis was restricted to family level.

A specific $Z$ test was used (Scherrer, 1984). For each specimen, the ratio $\mathrm{Xi}=$ percentage of pollen consumed of a particular plant family / percentage of ground occupied by this family at each site was calculated. Then, the number of adult specimens of each species of chrysopid each season was determined.

$\mathrm{Z}=(\overline{\mathrm{X}}-1) / \sigma$, with $\overline{\mathrm{X}}=$ average of Xi for a plant family and $\sigma=$ standard error. In the case of a random choice, $\bar{X}=1$. Plants are considered to be foraged randomly when $-1.96<\mathrm{Z}<1.96$.
This $\mathrm{Z}$ test is not significant when the number of observations is less than 15 .

\section{RESULTS}

\section{Chrysoperla spp. feeding}

Chrysoperla carnea and Ch. lucasina collection dates, number of specimens examined for gut contents, and number and percentage that contained pollen or honeydew, are presented in Table 2.

Among the 235 Chrysoperla adults collected, 173 were Ch. carnea and $62 \mathrm{Ch}$. lucasina. Both species of Chrysoperla contained pollen from week 12 to week 36, i.e. in spring and summer, while in autumn $98 \%$ contained mainly honeydew. Therefore, the pollen choice of green lacewings collected before mid-September was investigated.

In spring, from week 12 to 18 , a few specimens of diapausing adults leaving overwintering sites were collected. No specimen was caught in weeks 20 to 22 , the spring generation appeared in week 24 , at the beginning of summer.

Green lacewing adults consumed pollen of 28 plant families, of which 25 were present at the sites studied (Table 3). In the lacewing diverticula, there was pollen from crop plants, such as cabbage (Brassicaceae), leek (Liliaceae), carrot (Apiaceae) and alfalfa (Fabaceae), and wild plants such as Asteraceae, Chenopodiaceae, Gramineae and Ranunculaceae. Pollen of some uncommon plant families, such as Aristolochiaceae, which occur at one site, were also consumed. Adults seem to feed near their resting-places. Nevertheless, pollen of 26 commonly available plant families was not consumed, such as Agavaceae, Araceae, Convolvulaceae, Geraniaceae, Cucurbitaceae and Malvaceae.

Plants flowering in April, May, September and October, such as Agavaceae, Araceae, Buxaceae, Cupressaceae, Fagaceae and Resedaceae were rarely or not represented because very few Chrysoperla adults were collected during these months: the spring generation was still in the larval stage and adults only consume honeydew in autumn. Vitaceae flower in June but no lacewings were present at the site (Ambillou-Château), which includes some vineyards. 
TABLE 2. Number and percentage of Chrysoperla carnea and Ch. lucasina adults collected from March to October 2004 in four agroecosystems in western France of which the diverticula were examined for pollen and honeydew.

\begin{tabular}{|c|c|c|c|c|c|}
\hline $\begin{array}{r}\text { Collectic } \\
\text { season a } \\
\text { num }\end{array}$ & $\begin{array}{l}\text { dates: } \\
\text { week } \\
\text { er }\end{array}$ & $\begin{array}{c}\text { Chrysoperla } \\
\text { species }\end{array}$ & $\begin{array}{c}\text { No of } \\
\text { specimens } \\
\text { examined }\end{array}$ & $\begin{array}{l}\text { No and }(\%) \\
\text { with pollen }\end{array}$ & $\begin{array}{l}\text { No and } \\
(\%) \text { with } \\
\text { honeydew }\end{array}$ \\
\hline Spring & 12 & lucasina & 1 & $1(100)$ & $0(0)$ \\
\hline & 14 & carnea & 3 & $1(33)$ & $1(33)$ \\
\hline & & lucasina & 1 & $1(100)$ & $0(0)$ \\
\hline & 16 & carnea & 16 & $12(75)$ & $1(6)$ \\
\hline & 18 & carnea & 4 & $1(25)$ & $0(0)$ \\
\hline & & lucasina & 1 & $0(0)$ & $0(0)$ \\
\hline Summer & 24 & lucasina & 3 & $3(100)$ & $0(0)$ \\
\hline & 26 & carnea & 10 & $4(40)$ & $0(0)$ \\
\hline & & lucasina & 4 & $3(75)$ & $0(0)$ \\
\hline & 28 & carnea & 7 & $5(71)$ & $0(0)$ \\
\hline & & lucasina & 1 & $1(100)$ & $0(0)$ \\
\hline & 30 & carnea & 8 & $5(62.5)$ & $0(0)$ \\
\hline & & lucasina & 8 & $8(100)$ & $0(0)$ \\
\hline & 32 & carnea & 28 & $19(68)$ & $0(0)$ \\
\hline & & lucasina & 9 & $5(56)$ & $0(0)$ \\
\hline & 34 & carnea & 38 & $22(58)$ & $0(0)$ \\
\hline & & lucasina & 25 & $19(76)$ & $0(0)$ \\
\hline & 36 & carnea & 21 & $7(33)$ & $5(24)$ \\
\hline & & lucasina & 5 & $3(60)$ & $0(0)$ \\
\hline Autumn & 38 & carnea & 5 & $0(0)$ & $5(100)$ \\
\hline & & lucasina & 1 & $0(0)$ & $1(100)$ \\
\hline & 40 & carnea & 7 & $0(0)$ & $7(100)$ \\
\hline & & lucasina & 1 & $0(0)$ & $1(100)$ \\
\hline & 42 & carnea & 10 & $1(10)$ & $10(90)$ \\
\hline & & lucasina & 1 & $0(0)$ & $1(100)$ \\
\hline & 44 & carnea & 16 & $0(0)$ & $\begin{array}{r}16 \\
(100)\end{array}$ \\
\hline & & lucasina & 1 & $0(0)$ & $1(100)$ \\
\hline & & Total & 233 & 120 & 49 \\
\hline
\end{tabular}

Only three species of Primulaceae occur at the four sites: Anagallis tenella L., which closes its flowers at twilight, Primula veris L. flowering in April-May and Lysimachia nummularia $\mathrm{L}$. The pollen of none of these plants were present in our dissections, whereas Ducarme (2000) records that the pollen of Primulaceae, as well as Rubiaceae and Violaceae, is consumed by Chrysoperla carnea s. 1.

Agavaceae, Gentianaceae, Onagraceae and Verbenaceae were planted out in small spots and covered less than $1.5 \%$ of the surface area. When the area occupied by a particular species of plant is small, there is little chance their pollen will be collected and found in the diverticula of chrysopids.

As all the plants were either not easily available, or too rare, the hypothesis that they were repellent needs to be tested. For example, the pollen of Begoniaceae might not

TABLE 3. Percentage cover of the various plant families and the percentage of adults of the common green lacewings that had consumed pollen in four agroecosystems in western France.

\begin{tabular}{|c|c|}
\hline Plant families & $\begin{array}{l}\text { Total surface } \\
\text { occupied (\%) }\end{array}$ \\
\hline
\end{tabular}

\begin{tabular}{lll}
\hline Aceraceae & 1.5 & 0.0
\end{tabular}

$\begin{array}{lll}\text { Agavaceae } & 0.1 & 0.0\end{array}$

Apiaceae $\quad 46.1 \quad 6.1$

Aquifoliaceae $\quad 0.0 \quad 0.1$

$\begin{array}{lll}\text { Araceae } & 0.2 & 0.0\end{array}$

Araliaceae $\quad 0.1 \quad 0.1$

Aristolochiaceae $\quad 4.0 \quad 0.4$

Asteraceae $\quad 43.7 \quad 5.4$

Begoniaceae $\quad 7.5 \quad 0.0$

$\begin{array}{lll}\text { Betulaceae } & 11.4 & 0.4\end{array}$

$\begin{array}{lll}\text { Brassicaceae } & 74.0 & 18.0\end{array}$

Buxaceae $\quad 0.8 \quad 0$

$\begin{array}{lll}\text { Caprifoliaceae } & 0.8 & 0.4\end{array}$

Caryophyllaceae $\quad 16.5 \quad 2.4$

Chenopodiaceae-Amaranthaceae $\quad 15.0 \quad 18.6$

$\begin{array}{lll}\text { Convolvulaceae } & 17.2 & 0.0\end{array}$

Cucurbitaceae $\quad 7.5 \quad 0.0$

$\begin{array}{lll}\text { Cupressaceae } & 9.4 & 0.0\end{array}$

Ericaceae $\quad 1.5 \quad 0.1$

Euphorbiaceae $\quad 11.4 \quad 0.5$

$\begin{array}{lll}\text { Fabaceae } & 32.5 & 6.4\end{array}$

Fagaceae $\quad 18.8 \quad 0.0$

$\begin{array}{lll}\text { Gentianaceae } & 0.1 & 0.0\end{array}$

$\begin{array}{lll}\text { Geraniaceae } & 12.8 & 0.0\end{array}$

$\begin{array}{lll}\text { Gramineae } & 27.0 & 10.3\end{array}$

Hydrangeaceae $\quad 1.5 \quad 0.0$

$\begin{array}{lll}\text { Hyperaceae } & 7.5 & 0.0\end{array}$

Iridaceae $\quad 0.4 \quad 0.0$

Juglandaceae $\quad 9.6 \quad<0.1$

$\begin{array}{lll}\text { Lamiaceae } & 13.8 & 0.6\end{array}$

$\begin{array}{lll}\text { Lauraceae } & 0.4 & 0.0\end{array}$

$\begin{array}{lll}\text { Liliaceae } & 71.7 & 12.0\end{array}$

$\begin{array}{lll}\text { Logoniaceae } & 0.1 & 0.0\end{array}$

$\begin{array}{lll}\text { Malvaceae } & 3.0 & 0.0\end{array}$

$\begin{array}{lll}\text { Moraceae } & 1.5 & 0.0\end{array}$

$\begin{array}{lll}\text { Onagraceae } & 1.5 & 0.0\end{array}$

$\begin{array}{lll}\text { Papaveraceae } & 1.6 & 0.8\end{array}$

Pinaceae $\quad 0.1 \quad 3.7$

$\begin{array}{lll}\text { Plantaginaceae } & 15.0 & 1.2\end{array}$

$\begin{array}{lll}\text { Polygonaceae } & 15.0 & 0.1\end{array}$

$\begin{array}{lll}\text { Primulaceae } & 12.1 & 0.0\end{array}$

$\begin{array}{lll}\text { Ranunculaceae } & 19.0 & 0.8\end{array}$

$\begin{array}{lll}\text { Resedaceae } & 0.1 & 0.0\end{array}$

$\begin{array}{lll}\text { Rosaceae } & 65.5 & 3.9\end{array}$

$\begin{array}{lll}\text { Rubiaceae } & 0.8 & 0.0\end{array}$

Scrophulariaceae $\quad 10.5 \quad 0.0$

Solanaceae $\quad 10.0 \quad 0.2$

$\begin{array}{lll}\text { Tamaricaceae } & 0.0 & 0.2\end{array}$

$\begin{array}{lll}\text { Taxaceae } & 0.0 & 0.1\end{array}$

$\begin{array}{lll}\text { Tiliaceae } & 0.3 & 0.2\end{array}$

Urticaceae $\quad 11.3 \quad 3.3$

$\begin{array}{lll}\text { Valerianaceae } & 0.8 & 0.0\end{array}$

$\begin{array}{lll}\text { Verbenaceae } & 0.1 & 0.0\end{array}$

$\begin{array}{lll}\text { Violaceae } & 2.3 & 0.0\end{array}$

$\begin{array}{lll}\text { Vitaceae } & 9.4 & 0.0\end{array}$ 


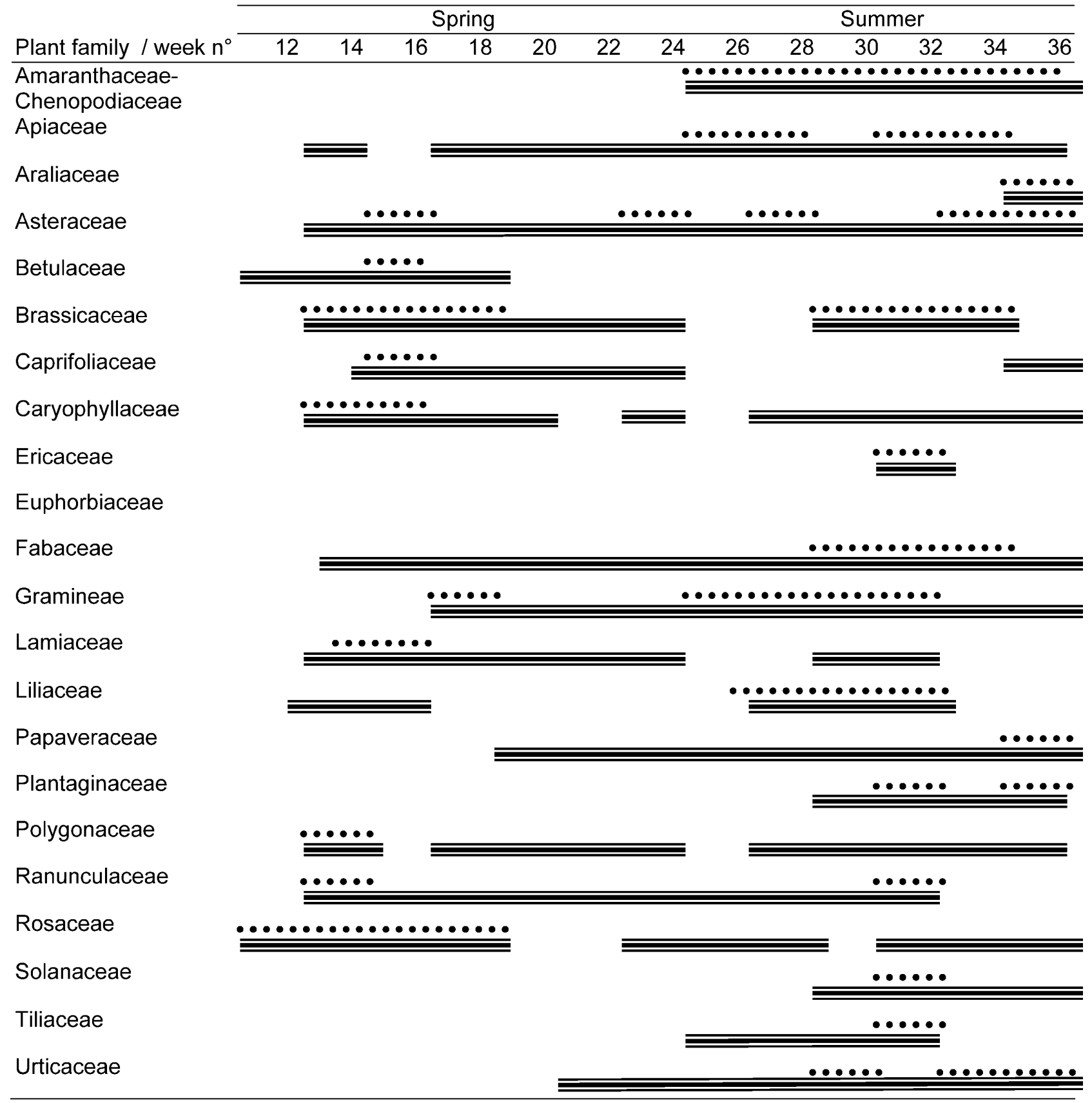

Fig. 1. Pollen consumed by the common green lacewings in four agroecosystems in western France from March to October 2004: comparison of the flowering time of the plants (black and white straight lines) and when the pollen was consumed (dotted lines).

be consumed in spite of it being available in large quantities.

In the laboratory, a deterrence was observed when Chrysoperla carnea adults were offered two plants, Dracocephalum modalvia L. (Lamiaceae) and Gerbera sp. (Asteraceae), at $22^{\circ} \mathrm{C}$ and a $16 \mathrm{~h}$ photoperiod. In a choice situation, they were rejected (total number of specimens $=$ 30 with 5 repetitions) and in a no-choice situation, Chrysoperla carnea adults died without eating any pollen.

\section{Feeding according to plant availability}

The flowering periods of 22 plants relative to when the pollen was consumed by Chrysoperla adults are presented in Fig. 1. The plants are searched when they flower, but not over the entire flowering period. For example, Apiaceae, Brassicaceae, Fabaceae, Liliaceae and Rosaceae are the crop plants whose flowering dates correspond to the period when chrysopids consume pollen. Carrot flowers from week 24 to 28 , rape 12 to 18 , cabbage 28 to 34 , alfalfa 28 to 34 , leek 26 to 32 at the site and trees in hedges, such as Prunus sp., and apple orchards flower in spring (Villenave et al., 2005). Large areas of field crops seem to attract Chrysoperla adults. 
TABLE 4. Z values for each plant family, the pollen of which was consumed by Chrysoperla in spring and summer in agroecosystems in western France from March to October 2004. Underlining indicates the families visited at random $(-1.96<\mathrm{Z}$ $<1.96$ ).

\begin{tabular}{|c|c|c|c|c|}
\hline \multirow[b]{2}{*}{ Species } & \multicolumn{2}{|l|}{ Spring } & \multicolumn{2}{|l|}{ Summer } \\
\hline & Plant Family & Z & Plant Family & Z \\
\hline \multirow[t]{13}{*}{$\begin{array}{l}\text { carnea } \\
\text { sensu Henry }\end{array}$} & Asteraceae & -8.82 & Apiaceae & -2.92 \\
\hline & Betulaceae & -23.22 & Aristolochiaceae & -7.02 \\
\hline & Brassicaceae & 8.44 & Asteraceae & -7.53 \\
\hline & Caryophylaceae & 7.91 & Brassicaceae & -2.76 \\
\hline & Gramineae & -68.21 & $\begin{array}{l}\text { Chenopodiaceae- } \\
\underline{\text { Amaranthaceae }}\end{array}$ & -1.34 \\
\hline & Lamiaceae & -12.68 & Euphorbiaceae & -7.04 \\
\hline & Polygonaceae & -99.38 & Fabaceae & -0.59 \\
\hline & Ranunculaceae & -116.00 & $\underline{\text { Gramineae }}$ & -1.10 \\
\hline & Rosaceae & -3.81 & $\underline{\text { Liliaceae }}$ & 0.05 \\
\hline & & & Plantaginaceae & -186.20 \\
\hline & & & $\underline{\text { Ranunculaceae }}$ & 0.33 \\
\hline & & & Solanaceae & -30.00 \\
\hline & & & $\underline{\text { Urticaceae }}$ & -1.31 \\
\hline \multirow[t]{9}{*}{ lucasina } & & & Apiaceae & -6.09 \\
\hline & & & $\underline{\text { Asteraceae }}$ & -1.82 \\
\hline & & & Brassicaceae & -5.09 \\
\hline & & & $\begin{array}{l}\text { Chenopodiaceae- } \\
\text { Amaranthaceae }\end{array}$ & 1.48 \\
\hline & & & Ericaceae & -5.22 \\
\hline & & & Fabaceae & -6.89 \\
\hline & & & Gramineae & 0.50 \\
\hline & & & $\underline{\text { Liliaceae }}$ & -0.26 \\
\hline & & & Urticaceae & -2.38 \\
\hline
\end{tabular}

Therefore, the pollen of plants that is not consumed is either not available or available in too small a quantity because of their phenology, whereas plants whose pollen is regularly consumed occur in large patches in agroecosystems $(>1.5 \%)$.

Are Ch. carnea and Ch. lucasina opportunists? Are some plants more attractive than others?

\section{Plant attractivity}

To test whether they are opportunists, the relation between the plants present at the site and whether their pollen was consumed was analysed using a $\chi^{2}$ test. The observed result corresponds to that predicted $\left(\chi^{2}\right.$ obs $=$ $3.50 \mathrm{E}-07, \chi^{2}$ theo $\left.=9.21, \mathrm{p}=0.01\right)$. It is the relation between the plants present at the site and the nature of the pollen consumed that indicates that Chrysoperla adults are opportunistic feeders. The more precise $\mathrm{Z}$ test was applied to determine whether the plants were foraged at random, and some were more attractive than others. As the periods of flight activity of the two species, $C h$. carnea and Ch. lucasina, differs, with the latter species collected only in summer and in low vegetation, the results for each species were analysed separately. Pollen of the different plant families was consumed at random,
TABLE 5. List of plant families, their flowering dates and phenological traits occurring in four agroecosystems from March to August 2004 in western France, the pollen of which was not consumed by the common green lacewings.

\begin{tabular}{|c|c|c|}
\hline & Flowering dates & Phenology \\
\hline Aceraceae & April-May & \\
\hline Agavaceae & July & \\
\hline Araceae & April-May & \\
\hline Begoniaceae & July-September & \\
\hline Buxaceae & April-May & \\
\hline Convolvulaceae & May-September & Close at twilight \\
\hline Cucurbitaceae & July-September & Close at twilight \\
\hline Cupressaceae & April-May & \\
\hline Fagaceae & April-May & \\
\hline Gentianaceae & July & \\
\hline Geraniaceae & April-December & Close at twilight \\
\hline Hydrangeaceae & July & \\
\hline Hyperaceae & July-August & \\
\hline Iridaceae & April-May & \\
\hline \multicolumn{3}{|l|}{ Lauraceae } \\
\hline Logoniaceae & June-July & \\
\hline Malvaceae & May-October & Close at twilight \\
\hline \multicolumn{3}{|l|}{ Moraceae } \\
\hline Onagraceae & August-September & \\
\hline Primulaceae & April-September & \\
\hline Resedaceae & September & \\
\hline Rubiaceae & April-June & \\
\hline \multicolumn{2}{|c|}{ Scrophulariaceae April-October } & Few species, Veronica sp. \\
\hline Valerianaceae & April-May & \\
\hline Verbenaceae & July-August & \\
\hline Violaceae & April, July, September & \\
\hline Vitaceae & June & \\
\hline
\end{tabular}

because $-1.96<\mathrm{Z}<1.96$ was recorded for few plant families (Table 4).

In spring, Ch. carnea consumed pollen of plants of mainly two families: Brassicaceae and Caryophylaceae. Caryophylaceae were abundant at the sites. The pollen of the species of Brassicaceae most consumed was from Brassica napus L. although the nearest rape field was about $500 \mathrm{~m}$ away. Thus, adults either flew to the field and came back, or flew directly from the rape field to the site.

In summer, there is no difference in the feeding behaviour of the two species: the crop and wild plants present in large patches (Urticaceae, Chenopodiaceae, Amaranthaceae and Asteraceae) were foraged at random. The pollen of other plant families was not consumed or only in small quantities.

\section{DISCUSSION AND CONCLUSION}

The gut analysis gave an insight into the feeding behaviour and flight activity of common green lacewings.

The food of Chrysoperla sp. changes with the seasons. In autumn, they consume mainly honeydew, which 
probably provides the necessary energy for the fat reserves of diapausing adults (Lemesle et al., 1998). Yeasts, such as Torulopsis sp., participate in the digestion of the honeydew in the diverticula of chrysopids (Hagen et al., 1970). In spring and summer, they consume pollen, nectar and honeydew because saccharides are essential for the adults, which mainly feed near their resting-places, in hedges (Duelli, 2001). They also seem to be opportunistic and do not select certain pollen, which was also noted by Ducarme (2000) and van Impe et al. (2002). However, some plants are never foraged for pollen. To account for this, several hypotheses have been proposed: (i) some plants are unattractive, (ii) or too rare, (iii) or they flower at times other than when the chrysopids are foraging for pollen (van Impe et al., 2002) or their flowers close at twilight.

The plant families of which pollen is never consumed (Table 5), the Convolvulaceae, Geraniaceae, Cucurbitaceae, Malvaceae and Scrophulariaceae have flowers that close at twilight. Therefore, the pollen of these plants is not available during that period of the day when Chrysoperla adults forage for pollen.

Pollen is consumed according to its availability determined by time of flowering and abundance. Pollen of scattered plants is not consumed as much as that of aggregated plants. Green lacewings seem to be attracted to large patches of flowering plants. In addition, the presence of honeydew on plants appears to influence the feeding behaviour of Chrysoperla (Duelli, 1987). Honeydew and nectar provide a supplementary food and source of the essential yeast symbionts.

In conclusion, we suggest that a permanent source of pollen and honeydew should be provided for common green lacewing adults at the borders and surroundings of crops. The vegetation should include plants that flower at different periods and throughout the period of flight activity of the chrysopids.

ACKNOWLEDGEMENTS. We would like to thank P. Aupinel and J.-F. Odoux (INRA, Le Magneraud) for the loan of equipment and C. Ferrier (Université d'Angers) for reviewing the English version of this manuscript. Thanks also to M. Canard (Toulouse, France) and to two anonymous reviewers for improving the manuscript.

\section{REFERENCES}

Aupinel P., Genissel A., Taséi J.-N., Poncet J. \& Gomond S. 2001: Collection of spring pollens by Bombus terrestris queens. Assessment of attractiveness and nutritive value of pollen diets. Acta Hort. 561: 101-105.

BalidDaWA C.W. 1985: Plant species and crop pest control. An analytical review. Insect Sci. Appl. 6: 479-487.

Barbosa P. 1998: Conservation Biological Control. Academic Press, New York, 396 pp.

BozsiK A. 1992: Natural adult food of some important Chrysopa species (Plannipennia: Chrysopidae). Acta Phytopatol. Entomol. Hung. 27: 141-146.

Colley M.R. \& LunA J.M. 2000: Relative attractiveness of potential beneficial insectary plants to aphidophagous hoverflies (Diptera: Syrphidae). Environ. Entomol. 29: 1054-1059.

Ducarme V. 2000: Etude de l'Activité de la Chrysope commune Chrysoperla carnea (Stephens) en Verger de Pommiers. MSc dissertation in biological sciences, Université Catholique de Louvain, $102 \mathrm{pp}$.

Duelli P. 1987: The influence of food on the oviposition-site selection in a predatory and a honeydew-feeding lacewing species (Plannipennia: Chrysopidae). Neuroptera Internat. 4: 205-210.

Duelli P. 2001: Lacewings in field crops. In McEwen P.K., New T.R. \& Whittington A.E. (eds): Lacewings in the Crop Environment. Cambridge University Press, Cambridge, UK, pp. $158-171$.

HAGEN K.S. \& TASSAN R.L. 1972 : Exploring nutritional roles of extracellular symbiontes on the reproduction of honeydew feeding adult chrysopids and tephritids. In Rodriquez J.G. (ed): Insect and Mite Nutrition. North-Holland Publ., Amsterdam, pp. 323-351.

Hagen K.S., Tassan R.L. \& Sawall E.F. JR. 1970: Some ecophysiological relationships between certain Chrysopa, honeydews and yeasts. Boll. Lab. Entomol. Agr. Filippo Silvestri Portici 28: 113-134.

Hagen K.S., Greany P., Sawall E.F. JR. \& Tassan R.L. 1976: Tryptophan in artificial honeydews as a source of an attractant for adult Chrysopa carnea. Environ. Entomol. 5: 458-468.

Henry C.S., Brooks S.J., Johnson J.B. \& Duelli P. 1996: Chrysoperla lucasina (Lacroix): a distinct species of green lacewing confirmed by acoustical analysis (Neuroptera: Chrysopidae). Syst. Entomol. 21: 205-218.

Henry C.S., Brooks S.J., Duelli P. \& Johnson J. B. 2002 : Discovering the true Chrysoperla carnea (Insecta: Neuroptera: Chrysopidae) using song analysis, morphology, and ecology. Ann. Entomol. Soc. Amer. 95: 172-191.

HoDEK I. 1973: Life history and biological properties. In Hodek I. (ed.): Biology of Coccinellidae. W. Junk, The Hague, 260 pp.

Hyde H.A. \& Adams K.F. 1958: An Atlas of Airborne Pollen Grains. Macmillan, London, 112 pp.

Impe G. van, Mignon M., Bribosia E. \& Lebrun P. 2002: Impact d'une haie et de bandes fleuries sur les auxiliaires des vergers de pommiers. Journées Techniques Nationales Fruits et Légumes Biologiques, December 2002. Morlaix, France, pp. $72-78$.

Lemesle A., Thierry D., Foussard F., Canard M. 1998: Preliminary study on lipids in Chrysoperla kolthoffi (Navás) during diapause (Neuroptera: Chrysopidae). In Panelius S.P. (ed.): Neuropterology 1997. Proceedings of the Sixth International Symposium on Neuropterology 1997, Helsinki, Finland. Acta Zool. Fennica 209: 141-144.

NEw T.R. 1975: Lacewings (Neuroptera) as biological control agents. Victor. Entomol. 5: 102-103.

Nicholls C. \& Altieri M. 2002: Biodiversidad y diseno agroecologico: un estudio de caso de manejo de plagas en vinedos. Man. Integr. Plagas Agroecol. 65: 50-64.

Paulian M. 2001: The green lacewings of Romania, their ecological patterns and occurrence in some agricultural crops. In McEwen P.K., New T.R. \& Whittington A.E. (eds): Lacewings in the Crop Environment. Cambridge University Press, Cambridge, UK, pp. 498-512.

PRINCIPI M.M. \& CANARD M. 1984: Feeding habits. In Canard M., Séméria Y. \& New. T.R. (eds): Biology of Chrysopidae. W. Junk, The Hague, pp. 76-92.

SCHERRER B. 1984: Biostatistique. Gaëtan Morin, Boucherville, Canada, $850 \mathrm{pp}$.

STELZL M. 1991: Untersuchungen zu Nahrungsspektren mitteleuropäischer Neuropteren-Imagines (Neuropteroidea, Insecta) mit einer Diskussion über deren Nützlichkeit als Opponenten von Pflanzenschädlingen. J. Appl. Entomol. 111: 469-477. 
Theunissen J. \& Den Ouden H. 1980: Effects of intercropping with Spergula arvensis on pests of brussels sprouts. Entomol. Exp. Appl. 27: 260-268.

Thierry D., Cloupeau R. \& Jarry M. 1992: La chrysope commune Chrysoperla carnea (Stephens) sensu lato dans le centre de la France: mise en évidence d'un complexe d'espèces (Insecta: Neuroptera: Chrysopidae). In Canard M., Aspöck H. \& Mansell M.W. (eds): Current Research in Neuropterology, Proceedings of the Fourth International Symposium on Neuropterology 1991, Bagnères-de-Luchon, France. Sacco, Toulouse, pp. 379-392.

Thierry D., Cloupeau R. \& Jarry M. 1994: Variation in the overwintering ecophysiological traits in the common green lacewing west Palearctic complex (Neuroptera, Chrysopidae). Acta Oecol. / Intern. J. Ecol. 15: 593-606.

Thierry D., Cloupeau R. \& Jarry M. 1996: Distribution of the sibling species of the common green lacewing Chrysoperla carnea (Stephens) in Europe (Insecta: Neuroptera: Chrysopidae). In Canard. M., Aspöck H. \& Mansell M.W. (eds): Pure and Applied Research in Neuropterology. Proceedings of the
Fifth International Symposium on Neuropterology 1994, Cairo, Egypt. Sacco, Toulouse, pp. 233-240.

Thierry D., Cloupeau R., Jarry M. \& Canard M. 1998: Discrimination of the West-Palaearctic Chrysoperla Steinmann species of the carnea Stephens group by means of claw morphology (Neuroptera, Chrysopidae). In Panelius S.P. (ed.): Neuropterology 1997. Proceedings of the Sixth International Symposium on Neuropterology 1997, Helsinki, Finland. Acta Zool. Fenn. 209: 255-262.

Thies C. \& TscharntKe T. 1999: Landscape structure and biological control in agroecosystems. Science 285: 893-895.

Villenave J., Thierry D., Al Mamun A., Lodé T. \& RatMorris É. 2005: The pollens consumed by Chrysoperla lucasina and Ch. affinis (Neuroptera: Chrysopidae) in cabbage crop environment in western France. Eur. J. Entomol. 102: 547-562.

Yeboah Gyan K. \& Woodell S.R.J. 1987: Analysis of insect pollen loads and pollination efficiency of some common insect visitors of four species of woody Rosaceae. Funct. Ecol. 1: 269-274.

Received September 23, 2005; revised and accepted January 30, 2006 